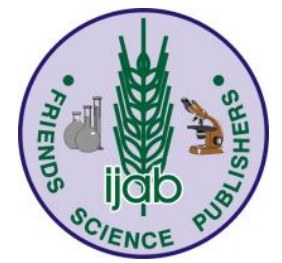

\title{
Effect of Brassinosteroid and Selenium on Uptake and Accumulation of Chromium in Yellow Flag (Iris pseudacorus)
}

\author{
Bo Xu, Jinyong Yu, Tian Xie, Yaolu Li, Ludong Yang, Yong Yu, Yanhui Chen* and Guo Wang \\ Fujian Provincial Key Laboratory of Soil Environmental Health and Regulation, College of Resources and Environmental \\ Sciences, Fujian Agriculture and Forestry University, Fuzhou Fujian, 350002, China \\ "For correspondence: 382072058@qq.com
}

\begin{abstract}
A hydroponic experiment was conducted to investigate the effect of brassinosteroids $(\mathrm{Br})$ and selenium $(\mathrm{Se})$ on iron plaque (IP) formation and chromium (Cr) accumulation and uptake by Iris pseudacorus L. (yellow flag). Yellow flag seedlings (4 week old seedlings) were grown under $0.1 \mathrm{mg} \mathrm{L}^{-1} \mathrm{Br}$ (24-epibrassinolide (Br24) or 28-homobrassinolide (Br28)) or $0.5 \mathrm{mg} \mathrm{L}^{-1}$ $\mathrm{Se}$ (Se(IV) or Se(VI)) for 2 weeks. Then seedlings with or without IP induction $\left(60 \mathrm{mg} \mathrm{Fe}^{2+} \mathrm{L}^{-1}\right.$ for 3 days) were exposed to 5 $\mathrm{mg} \mathrm{L}^{-1}$ hexavalent chromium $[\mathrm{Cr}(\mathrm{VI})]$ for 1 week. The results showed that $\mathrm{Cr}$ reduced Fe accumulation and uptake by yellow flag with or without IP; however, this effect was significantly neutralized by $\mathrm{Br}$, but not by Se. IP significantly enhanced $\mathrm{Cr}$ accumulation in DCB extract and the whole yellow flag seedling, and increased $\mathrm{Cr}$ content by $36 \% \mathrm{Br} 24$ and $\mathrm{Br} 28$ significantly enhanced $\mathrm{Cr}$ accumulation and uptake by yellow flag and increased $\mathrm{Cr}$ enrichment by 36 and $51 \%$ in the absence of IP, and 7 and $21 \%$ in the presence of IP, respectively. Se(IV) markedly improved $\mathrm{Cr}$ accumulation in the root, but $\mathrm{Cr}$ accumulation and uptake in the shoot and DCB extract were not affected by Se(IV) and $\mathrm{Se}(\mathrm{VI})$. Our study suggests that Br24 and $\mathrm{Br} 28$ can alleviate $\mathrm{Fe}$ loss caused by $\mathrm{Cr}$ stress and increase $\mathrm{Cr}$ accumulation and uptake by yellow flag seedlings. (C) 2017 Friends Science Publishers
\end{abstract}

Keywords: Chromium; Phytoremediation; Brassinosteroid; Iron plaque; Selenium

\section{Introduction}

Soil and water contamination by chromium $(\mathrm{Cr})$ received widespread attention due to its abundance and toxicity (Gao and Xia, 2011; Mashkoor et al., 2016; Ballesteros et al., 2017). Cr mainly consists of two valence states: $\mathrm{Cr}$ (III) and $\mathrm{Cr}(\mathrm{VI})$ in the environment (Rai et al., 1989). It has been classified as a Group I carcinogen, and $\mathrm{Cr}(\mathrm{VI})$ shows much more soluble and toxic to plants and human in comparison with the relatively immobile $\mathrm{Cr}$ (III) (Richard and Bourg, 1991; Smith et al., 1997). Cr contamination often occurs via anthropogenic pathways, including electroplating, leather, mining, manufacturing of pigments, dyes, textiles, etc (Gao and Xia, 2011). Consequently $\mathrm{Cr}$ could enter the human food chain by translocation, accumulation and uptake in soil, water, plants and animals, and pose potential health threat to humans (Xia et al., 2016). In this regard, it is extremely urgent to solve this environment problem. Recently, phytoremediation has gradually become a promising, economic and environment-friendly remediation technology to remove heavy metals in the environment (Singh et al., 2003; Hashim et al., 2011). Iris pseudacorus L. (yellow flag) as one of ornamental hydrophyte possesses characteristics of macrophytes with high efficiency to accumulate heavy metals (Mang et al., 2007; Xu et al., 2015). In addition, yellow flag, like most wetland plants, can form iron plaque (IP) on root surfaces under saturated or anaerobic condition.

Ferrous ion is oxidized by oxygen or antioxidant secreted from roots and is precipitated on root surfaces of wetland plants (Armstrong, 1964; Taylor et al., 1984). The Fe precipitation is called IP and is composed mainly of amorphous $\mathrm{Fe}$ oxyhydroxides and small amounts of crystalline Fe oxides (Hansel et al., 2001; Weiss et al., 2004; $\mathrm{Xu}$ and $\mathrm{Yu}, 2013)$. Several studies have reported that IP could adsorb metal(loid)s and decide their fate by blocking or improving their translocation into plants (Ye et al., 1998; Batty et al., 2000; Ye et al., 2003; Liu et al., 2004; Liu et al., 2007; Liu et al., 2008b; Xu and Yu, 2013; Xu et al., 2015). Various factors (such as amount of IP, metal(loid) type and concentration, $\mathrm{pH}$, etc.) could affect metal(loid) translocation and accumulation in plants. The effects of IP on $\mathrm{Cr}$ translocation and uptake in plants showed that IP could immobilize $\mathrm{Cr}$ on root surface of rice and yellow flag and significantly increased $\mathrm{Cr}$ uptake by yellow flag ( $\mathrm{Hu}$ et al., 2014a; Xu et al., 2015).

Brassinosteroids (Br) as vital regulators in plant development and growth can alleviate heavy metal toxicity through increasing antioxidant enzyme activity (Clouse and Sasse, 1998; Fariduddin et al., 2014). It was reported that $\mathrm{Br}$ could increase photosynthesis (Yu et al., 2004; Ahammed et al., 2013), which enhanced radial oxygen loss contributing 
to IP formation (Lai et al., 2012; Wu et al., 2012). Therefore, we hypothesized that $\mathrm{Br}$ might promote IP formation; and the combined effects of $\mathrm{Br}$ and IP could enhance $\mathrm{Cr}$ accumulation and uptake by yellow flag.

Selenium (Se), a nonessential element for plant growth, can also alleviate heavy metal $(\mathrm{Cd}, \mathrm{Pb}, \mathrm{Hg})$ toxicity to plants possibly through forming Se-metal complexes (Sasakura and T. Suzuki, 1998; Belzile et al., 2006; Fargasova et al., 2006; Hu et al., 2014b). Most studies focus on the role of Se in decreasing translocation and uptake of heavy metals in plants, but little information has been obtained on Se effect on phytoremediation in heavy metals in macrophytes. Qing et al. (2015) found that Se(IV) could protect plant from $\mathrm{Cr}$ stress through increasing antioxidants activity but did not affect $\mathrm{Cr}$ translocation in cabbage leaves. Besides, Se supply promoted As and Al uptake by Pteris vittata L. (Srivastava et al., 2009) and ryegrass (Cartes et $a l ., 2010)$. Taking together the above information, therefore, our objectives in the present study were (1) to test the influence of $\mathrm{Br}$ (24-epibrassinolide (Br24) and 28homobrassinolide (Br28)) or Se (Se(IV) and $\mathrm{Se}(\mathrm{VI})$ ) on IP formation and (2) to investigate the effect of $\mathrm{Br}$ or Se on $\mathrm{Cr}$ translocation and uptake by yellow flag with or without IP.

\section{Materials and Methods}

\section{Plant Culture and Experiment Treatment}

Seeds of yellow flag, obtained from Guanyin Lake, Fujian agriculture and forestry university, Fujian Province, China, were soaked in $30 \% \mathrm{v} / \mathrm{v} \mathrm{H}_{2} \mathrm{O}_{2}$ for $60 \mathrm{~min}$ and then were rinsed thoroughly using deionized water. These seeds were placed on moist quartz sand for 30 days for germination in greenhouse with temperature from $25-35^{\circ} \mathrm{C}$. Uniform seedlings were transferred to $1 / 3$ strength Hoagland nutrient solution ( $\mathrm{pH}$ 5.5) for 30 days. Then these seedlings were grown in nutrient solution with $\mathrm{Br} 24\left(0.1 \mathrm{mg} \mathrm{L}^{-1}\right), \mathrm{Br} 28(0.1$ $\left.\mathrm{mg} \mathrm{L} \mathrm{L}^{-1}\right), \mathrm{Se}(\mathrm{IV})\left(0.5 \mathrm{mg} \mathrm{L}^{-1}\right)$ and $\mathrm{Se}(\mathrm{VI})\left(0.5 \mathrm{mg} \mathrm{L}^{-1}\right)$, respectively. After two weeks, all seedlings were transferred in deionized water for $12 \mathrm{~h}$ and induced to form IP by adding $60 \mathrm{mg} \mathrm{Fe}^{2+} \mathrm{L}^{-1}\left(\mathrm{FeSO}_{4} \cdot 7 \mathrm{H}_{2} \mathrm{O}\right)$ into nutrient solution without $\mathrm{P}$ for 3 days. Afterwards these seedlings were grown in normal $1 / 3$ strength Hoagland nutrient solution for 3 days and then exposed to $5 \mathrm{mg} \mathrm{L}^{-1} \mathrm{Cr}\left(\mathrm{K}_{2} \mathrm{Cr}_{2} \mathrm{O}_{7}\right)$ for one week. A total of 16 treatments were as follows: control, IP, Cr, Br24, Br28, Se(IV), Se(VI), IP + Br24, IP + Br28, IP + $\mathrm{Se}(\mathrm{IV}), \mathrm{IP}+\mathrm{Se}(\mathrm{VI}), \mathrm{IP}+\mathrm{Cr}, \mathrm{IP}+\mathrm{Br} 24+\mathrm{Cr}, \mathrm{IP}+\mathrm{Br} 28+$ $\mathrm{Cr}, \mathrm{IP}+\mathrm{Se}(\mathrm{IV})+\mathrm{Cr}$, IP $+\mathrm{Se}(\mathrm{VI})+\mathrm{Cr}$. The nutrient solution was changed twice a week and the experiment was carried out in a greenhouse at $15-25^{\circ} \mathrm{C}$ with natural day/night sunlight. The full-strength Hoagland solution was composed of (mmol L-1): $\mathrm{KH}_{2} \mathrm{PO}_{4}(1.0), \mathrm{KNO}_{3}(5.0), \mathrm{Ca}\left(\mathrm{NO}_{3}\right)_{2} \cdot 4 \mathrm{H}_{2} \mathrm{O}$ (5.0), $\mathrm{MgSO}_{4} \cdot 7 \mathrm{H}_{2} \mathrm{O}(2.0) ; \mathrm{CuSO}_{4} \cdot 5 \mathrm{H}_{2} \mathrm{O}\left(3.2 \times 10^{-4}\right)$, $\mathrm{ZnSO}_{4} \cdot 7 \mathrm{H}_{2} \mathrm{O}\left(7.7 \times 10^{-4}\right), \mathrm{MnCl}_{2} \cdot 4 \mathrm{H}_{2} \mathrm{O}\left(9.2 \times 10^{-3}\right), \mathrm{H}_{3} \mathrm{BO}_{3}$ $\left(4.6 \times 10^{-2}\right), \quad \mathrm{H}_{2} \mathrm{MoO}_{4} \cdot 4 \mathrm{H}_{2} \mathrm{O} \quad\left(3.85 \times 10^{-4}\right), \quad \mathrm{Fe}(\mathrm{II})-$ ethylenediamine tetraaceticacid (EDTA) $\left(2.0 \times 10^{-2}\right)$.

\section{Chemical Analysis of Plant Samples}

At harvest, the whole plant of yellow flag was divided into shoot and root. The root was washed thoroughly using deionized water and was incubated in $50 \mathrm{~mL}$ dithionitecitrate-bicarbonate (DCB) solution containing $0.03 \mathrm{M}$ sodium citrate $\left(\mathrm{Na}_{3} \mathrm{C}_{6} \mathrm{H}_{5} \mathrm{O}_{7} \cdot 2 \mathrm{H}_{2} \mathrm{O}\right), \quad 0.125 \mathrm{M}$ sodium bicarbonate $\left(\mathrm{NaHCO}_{3}\right)$, and $1 \mathrm{~g}$ sodium dithionite $\left(\mathrm{Na}_{2} \mathrm{~S}_{2} \mathrm{O}_{4}\right)$ for $60 \mathrm{~min}$ at $25^{\circ} \mathrm{C}$ (Taylor and Crowder, 1983). Then washed the roots three times using deionized water and transferred these solution into $100 \mathrm{~mL}$ volumetric flask. DCB extracts solution was filtered using $0.22 \mu \mathrm{m}$ membrane filters and stored in $4^{\circ} \mathrm{C}$ for analysis. The shoots and roots were oven-dried at $65^{\circ} \mathrm{C}$ for $72 \mathrm{~h}$ and then were weighed. The dry plant samples were ground and transferred into digestion tubes for digestion according to $\mathrm{Xu}$ et al. (2015). Transferred digestion solution to a $100 \mathrm{~mL}$ volumetric flask and filtered the solution through $0.22 \mu \mathrm{m}$ membrane filters. A reagent blank and a standard referencematerial (bush twigs and leaves, GBW07603, Chinese National Certified Reference Material) were included as a quality control for digestion procedure and subsequent analysis.

The concentrations of $\mathrm{Fe}, \mathrm{Cr}, \mathrm{Cu}, \mathrm{Zn}, \mathrm{Mn}$ and $\mathrm{B}$ in plant samples were measured by Induced Couple PlasmaMass Spectrometer (ICP-MS, NexION 300X; Perkin Elmer, $\mathrm{NY}$ ), and the concentrations of $\mathrm{Fe}$ and $\mathrm{Cr}$ in DCB extracts were measured using a flame atomic absorption spectrophotometer (FAAS Solaar M6, Thermo Electron Corp., Waltham, MA, USA).

\section{Statistical Analysis}

Independent-sample T tests and ANOVA were conducted to test the effects of $\mathrm{Br}$ or Se with or without IP on biomass, distribution of $\mathrm{Fe}, \mathrm{Cr}, \mathrm{Cu}, \mathrm{Mn}, \mathrm{Zn}$ and $\mathrm{B}$ in leaves, roots, DCB extracts and the whole yellow flag seedlings exposed to $\mathrm{Cr}$ stress. Data presented are means $\pm \mathrm{SD}(n=3)$ and analyzed using least significant difference (LSD) at the 5\% level. The statistical analyses were carried out using SPSS software (19.0, SPSS, Inc., Chicago, IL, USA).

\section{Results}

\section{Plant Growth}

The shoot biomass of yellow flag was significantly increased by the combined effects of $\mathrm{Br} 24$ and IP, but not by other treatments. The root biomass was reduced by the combined effects of $\mathrm{Cr}$, IP and $\mathrm{Br} 24$ or $\mathrm{Se}$ (Se(IV) or $\mathrm{Se}(\mathrm{VI})$ ) (Fig. 1). Compared to Cr treatment, Br24 and Br28 markedly increased shoot growth of yellow flag exposed to $\mathrm{Cr}$ stress in the absence of IP, but not in the presence of IP. 


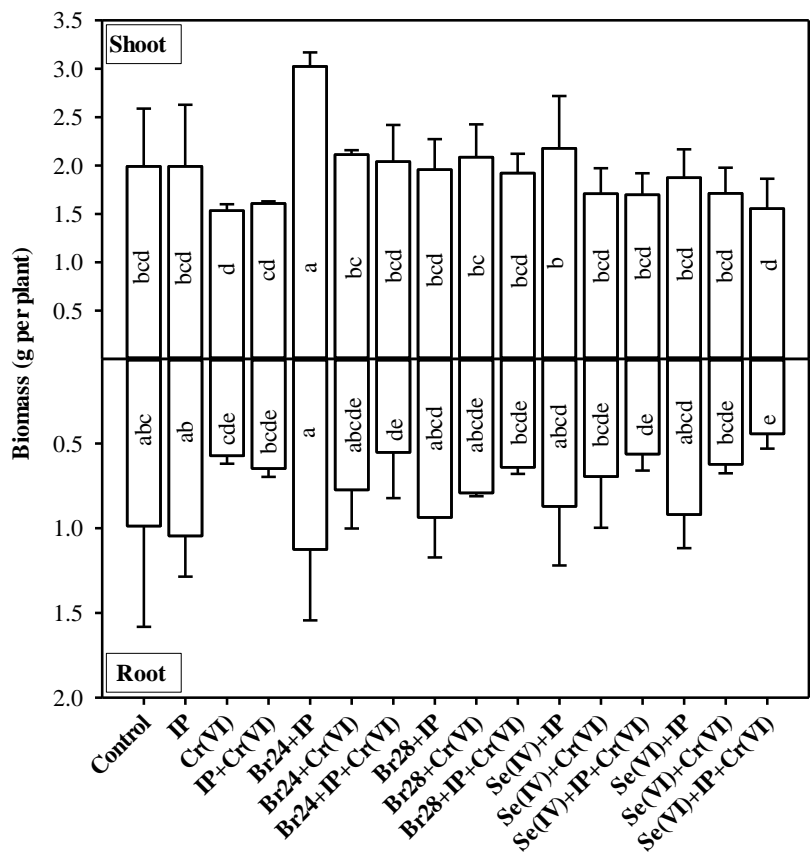

Fig. 1: Biomass of shoot and root of yellow flag (Iris pseudacorus L.) seedlings with brassinosteroid (24epibrassinolide (Br24): $0.1 \quad \mathrm{mg} \quad \mathrm{L}^{-1}$ and 28 homobrassinolide $(\mathrm{Br} 28): 0.1 \mathrm{mg} \mathrm{\textrm {L } ^ { - 1 }}$ ) and selenium (Se(IV): $0.5 \mathrm{mg} \mathrm{L}^{-1}$ and $\left.\mathrm{Se}(\mathrm{VI}): 0.5 \mathrm{mg} \mathrm{L}^{-1}\right)$ ) with or without iron plaque (IP) $\left(\mathrm{Fe}^{2+}: 0\right.$ or $\left.60 \mathrm{mg} \mathrm{L}^{-1}\right)$ under 0 or $0.5 \mathrm{mg} \mathrm{L}^{-1}$ hexavalent chromium $(\mathrm{Cr}(\mathrm{VI}))$ stress. Different letters indicate significant differences at $p<0.05$ in biomass of shoot and root of yellow flag seedlings. Data are means $\pm \mathrm{SD}, n=3$

\section{Analysis of Fe}

In the control group, $60 \mathrm{mg} \mathrm{Fe}{ }^{2+} \mathrm{L}^{-1}$ addition did not significantly affect $\mathrm{Fe}$ concentrations in $\mathrm{DCB}$ extracts; however, Fe addition increased DCB-Fe concentrations under $\mathrm{Cr}$ stress with or without $\mathrm{Br}(\mathrm{Br} 24$ and $\mathrm{Br} 28)$ or $\mathrm{Se}$ (Se(IV) and $\mathrm{Se}(\mathrm{VI})$ ) (Fig. 2). The Fe concentrations in root tissues were significantly increased by IP and the combined effects of IP and $\mathrm{Br}(\mathrm{Br} 24$ and $\mathrm{Br} 28)$ with or without $\mathrm{Cr}$, but not by $\mathrm{Se}(\mathrm{IV})$ and $\mathrm{Se}(\mathrm{VI})$ (Fig. 2). However, shoot Fe concentrations were not affected by IP and other treatments except at $\mathrm{Br} 28$. In the absence of IP, the combined treatments of $\mathrm{Se}(\mathrm{IV})$ and $\mathrm{Cr}$ decreased $\mathrm{Fe}$ concentrations in DCB extracts (Fig. 2). In the presence of IP, however, DCB$\mathrm{Fe}$ concentrations were significantly increased by the combined effects of $\mathrm{Br}(\mathrm{Br} 24$ and $\mathrm{Br} 28)$ and $\mathrm{Cr}$. Under $\mathrm{Cr}$ free treatment, $\mathrm{Br}$ did not affect $\mathrm{Fe}$ concentrations in shoots, roots and $\mathrm{DCB}$ extracts, but root $\mathrm{Fe}$ concentrations were significantly reduced by $\mathrm{Se}(\mathrm{IV})$ and $\mathrm{Se}(\mathrm{VI})$; and $\mathrm{Se}(\mathrm{VI})$ also decreased DCB-Fe concentrations (Fig. 2). Under Cr-free condition, Se(IV) supply markedly reduced Fe accumulation in DCB extract, root and whole yellow flag plant in the presence of IP (Fig. 3). Under $\mathrm{Cr}$ treatment, Fe
Table 1: Distribution of iron $(\mathrm{Fe})$ in shoot, root, dithionitecitrate-bicarbonate (DCB) extract and the whole plant of $I$. pseudacorus (yellow flag) seedlings with brassinosteroid (24-epibrassinolide (Br24): $0.1 \quad \mathrm{mg}^{-1}$ and 28homobrassinolide $\left.(\mathrm{Br} 28): 0.1 \mathrm{mg} \mathrm{\textrm {L } ^ { - 1 }}\right)$ and selenium (Se(IV): $0.5 \mathrm{mg} \mathrm{L}^{-1}$ and $\left.\mathrm{Se}(\mathrm{VI}): 0.5 \mathrm{mg} \mathrm{L}^{-1}\right)$ ) with or without iron plaque (IP) $\left(\mathrm{Fe}^{2+}: 0\right.$ or $\left.60 \mathrm{mg} \mathrm{L}^{-1}\right)$ under 0 or $0.5 \mathrm{mg} \mathrm{L}^{-1}$ hexavalent chromium $(\mathrm{Cr}(\mathrm{VI}))$ stress

\begin{tabular}{lllllllll}
\hline Treatment & & & \multicolumn{5}{c}{ Fe content (mg) } \\
\cline { 4 - 9 } & & & & & $\mathrm{Br} 24$ & $\mathrm{Br} 28$ & $\mathrm{Se}(\mathrm{IV})$ & $\mathrm{Se}(\mathrm{VI})$ \\
\hline $\mathrm{DCB}-\mathrm{Fe}$ & $\mathrm{A}$ & $+\mathrm{IP}$ & $+\mathrm{Cr}$ & 3.78 & 6.27 & 7.22 & 4.77 & 4.94 \\
& $\mathrm{~B}$ & $-\mathrm{IP}$ & $+\mathrm{Cr}$ & $1.58 * *$ & $2.41 *$ & $2.78 * *$ & $1.20 * *$ & $1.96 *$ \\
& $\mathrm{C}$ & $+\mathrm{IP}$ & $-\mathrm{Cr}$ & $6.88 * *$ & 6.32 & 5.76 & 4.39 & 6.26 \\
$\mathrm{Root}-\mathrm{Fe}$ & $\mathrm{A}$ & $+\mathrm{IP}$ & $+\mathrm{Cr}$ & 1.11 & 1.04 & 1.15 & 0.75 & 0.60 \\
& $\mathrm{~B}$ & $-\mathrm{IP}$ & $+\mathrm{Cr}$ & $0.43 * *$ & 0.64 & $0.65 *$ & 0.59 & 0.49 \\
& $\mathrm{C}$ & $+\mathrm{IP}$ & $-\mathrm{Cr}$ & $1.85 *$ & 1.37 & 1.22 & 0.90 & $1.39 *$ \\
Shoot-Fe & $\mathrm{A}$ & $+\mathrm{IP}$ & $+\mathrm{Cr}$ & 0.42 & 0.69 & 0.60 & 0.47 & 0.42 \\
& $\mathrm{~B}$ & $-\mathrm{IP}$ & $+\mathrm{Cr}$ & 0.37 & 0.37 & $0.40^{*}$ & 0.43 & 0.44 \\
& $\mathrm{C}$ & $+\mathrm{IP}$ & $-\mathrm{Cr}$ & 0.51 & 0.89 & 0.67 & 0.52 & 0.50 \\
Total-Fe & $\mathrm{A}$ & $+\mathrm{IP}$ & $+\mathrm{Cr}$ & 5.31 & 8.01 & 8.96 & 6.00 & 5.96 \\
& $\mathrm{~B}$ & $-\mathrm{IP}$ & $+\mathrm{Cr}$ & $2.38 * *$ & $3.43 *$ & $3.83 * *$ & $2.22 * *$ & 2.89 \\
& $\mathrm{C}$ & $+\mathrm{IP}$ & $-\mathrm{Cr}$ & $9.24 * *$ & 8.57 & 7.64 & 5.81 & 8.15 \\
\hline The “*”" or “**” labeled bars mean significant differences between A and B \\
group or A and C group at $p<0.05$ or $p<0.01$ in shoot, root, DCB extract \\
and the whole plant of yellow flag seedlings. Data are means \pm SD, $n=3$
\end{tabular}

accumulation in DCB extracts and whole plant was significantly enhanced by $\mathrm{Br} 24$ and $\mathrm{Br} 28$ regardless of formation or not of IP (Fig. 3). In comparison with the control seedlings, $\mathrm{Fe}$ accumulation in DCB extracts and whole plants was dramatically increased by IP or the combination of IP and $\mathrm{Br} 24$ under $\mathrm{Cr}$-free treatment (Fig. 3). Similarly, when compared to the control, $\mathrm{Br}(\mathrm{Br} 24$ and $\mathrm{Br} 28$ ) with IP enhanced Fe accumulation in DCB extracts under $\mathrm{Cr}$ treatment; and $\mathrm{Br} 28$ with IP promoted $\mathrm{Fe}$ uptake by whole plant (Fig. 3). Under Cr treatment, additionally, IP formation dramatically increased $\mathrm{Fe}$ accumulation in roots and DCB extracts, but not in shoots (Table 1). However, compared to $\mathrm{Cr}$-free treatment, $\mathrm{Cr}$ stress significantly reduced $\mathrm{Fe}$ accumulation in roots and DCB extracts in the presence of IP; and $\mathrm{Br}(\mathrm{Br} 24$ and $\mathrm{Br} 28)$ and $\mathrm{Se}(\mathrm{Se}(\mathrm{IV})$ and $\mathrm{Se}(\mathrm{VI})$ ) neutralized this effect (Table 1). The percentage of $\mathrm{Fe}$ in DCB extracts, roots and shoots was $5-19 \%, 10-27 \%$ and $54-83 \%$, respectively (Fig. 4).

\section{Analysis of $\mathrm{Cr}$}

The $\mathrm{Cr}$ concentrations in yellow flag were not affected by IP with or without $\mathrm{Br}$ or Se except $\mathrm{Cr}$ concentrations in $\mathrm{DCB}$ extracts under $\mathrm{Se}$ (VI) supply (Fig. 5). The Cr concentrations in shoots and roots were significantly increased by $\mathrm{Br} 24$ and Se(IV), respectively (Fig. 5). The results of enrichment content of $\mathrm{Cr}$ in yellow flag showed that compared to the seedlings without IP, Cr accumulation in DCB extract and whole plant was markedly increased by IP, but not by the combination of IP and $\mathrm{Br}(\mathrm{Br} 24$ and $\mathrm{Br} 28)$ or $\mathrm{Se}$ (Se(IV) and $\mathrm{Se}(\mathrm{VI}))$ (Fig. 6). In comparison with the control seedlings, $\mathrm{Br} 28$ and $\mathrm{Br} 24$ increased $\mathrm{Cr}$ accumulation in 


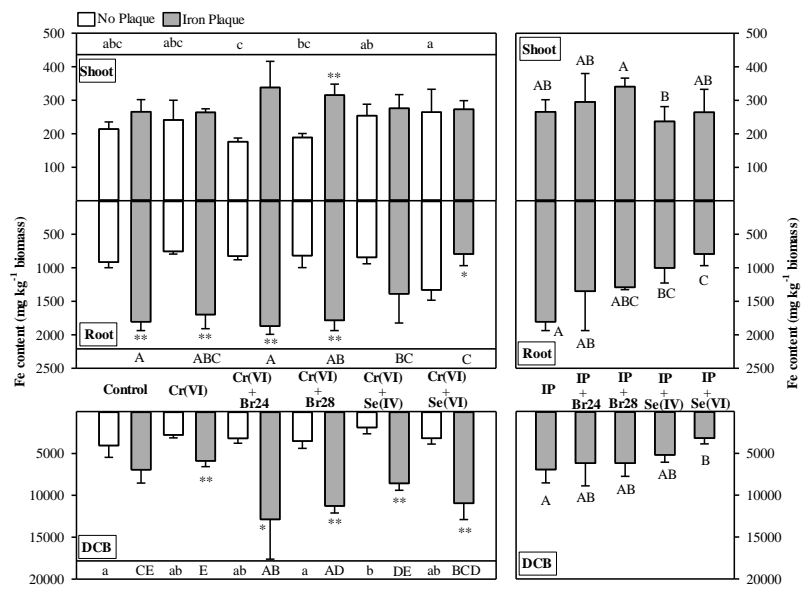

Fig. 2: Distribution of iron $(\mathrm{Fe})$ in shoot, root and dithionite-citrate-bicarbonate (DCB) extract of $I$. pseudacorus (yellow flag) seedlings with brassinosteroid (24-epibrassinolide $(\mathrm{Br} 24): 0.1 \quad \mathrm{mg} \mathrm{L} \mathrm{L}^{-1}$ and 28homobrassinolide (Br28): $0.1 \mathrm{mg} \mathrm{\textrm {L } ^ { - 1 }}$ ) and selenium (Se(IV): $0.5 \mathrm{mg} \mathrm{L}^{-1}$ and $\left.\mathrm{Se}(\mathrm{VI}): 0.5 \mathrm{mg} \mathrm{L}^{-1}\right)$ ) with or without iron plaque (IP) $\left(\mathrm{Fe}^{2+}: 0\right.$ or $\left.60 \mathrm{mg} \mathrm{L}^{-1}\right)$ under 0 or $0.5 \mathrm{mg} \mathrm{L}^{-1}$ hexavalent chromium $(\mathrm{Cr}(\mathrm{VI}))$ stress. Contents of Fe in shoot, root and DCB extract were presented as mg $\mathrm{kg}^{-1}$ biomass weight. Different letters indicate significant differences at $p<0.05$ in shoot, root and DCB extract of yellow flag seedlings (capital letters for no plaque group and lowercase letters for IP group). The “*” or “**” labeled bars mean significant differences between no plaque group and IP group at $p<0.05$ or $p<0.01$. Data are means $\pm \mathrm{SD}$, $n=3$

DCB extract and root tissue, respectively; and $\mathrm{Br}(\mathrm{Br} 24$ and $\mathrm{Br} 28$ ) enhanced $\mathrm{Cr}$ accumulation by whole plants (Fig. 6). In the absence of IP, compared to the control plants, $\mathrm{Br} 24, \mathrm{Br} 28, \mathrm{Se}(\mathrm{IV})$ and $\mathrm{Se}(\mathrm{VI})$ increased enrichment content of $\mathrm{Cr}$ by $36 \%, 51 \%, 19 \%$ and $27 \%$, respectively; and they increased that by $7 \%, 21 \%, 8 \%$ and $-6 \%$ in the presence of IP (Fig. 6). IP formation increased $\mathrm{Cr}$ enrichment content by $36 \%$ compared to the control seedlings (Fig. 6). The percentage of $\mathrm{Cr}$ in shoots, roots and DCB extracts was $2-7 \%, 13-23 \%$ and $73-84 \%$, respectively (Fig. 7).

\section{Analysis of $\mathrm{Cu}, \mathrm{Zn}, \mathrm{Mn}$ and $\mathrm{B}$}

Compared to the control seedlings, the concentrations of $\mathrm{Zn}$, $\mathrm{Mn}$ and $\mathrm{B}$ in root tissues were markedly reduced by $\mathrm{Cr}$; and $\mathrm{Mn}$ and $\mathrm{B}$ concentrations in shoots were significantly decreased by IP (Fig. 8). Mn loss in root of yellow flag exposed to $\mathrm{Cr}$ stress was significantly neutralized by IP or the combined effects of IP and Se(IV); and Zn loss was neutralized by the combined effects of IP and $\mathrm{Br} 28$; and B loss was counteracted by the combined effects of IP and $\mathrm{Br}$ (Br24 and Br28) (Fig. 8).

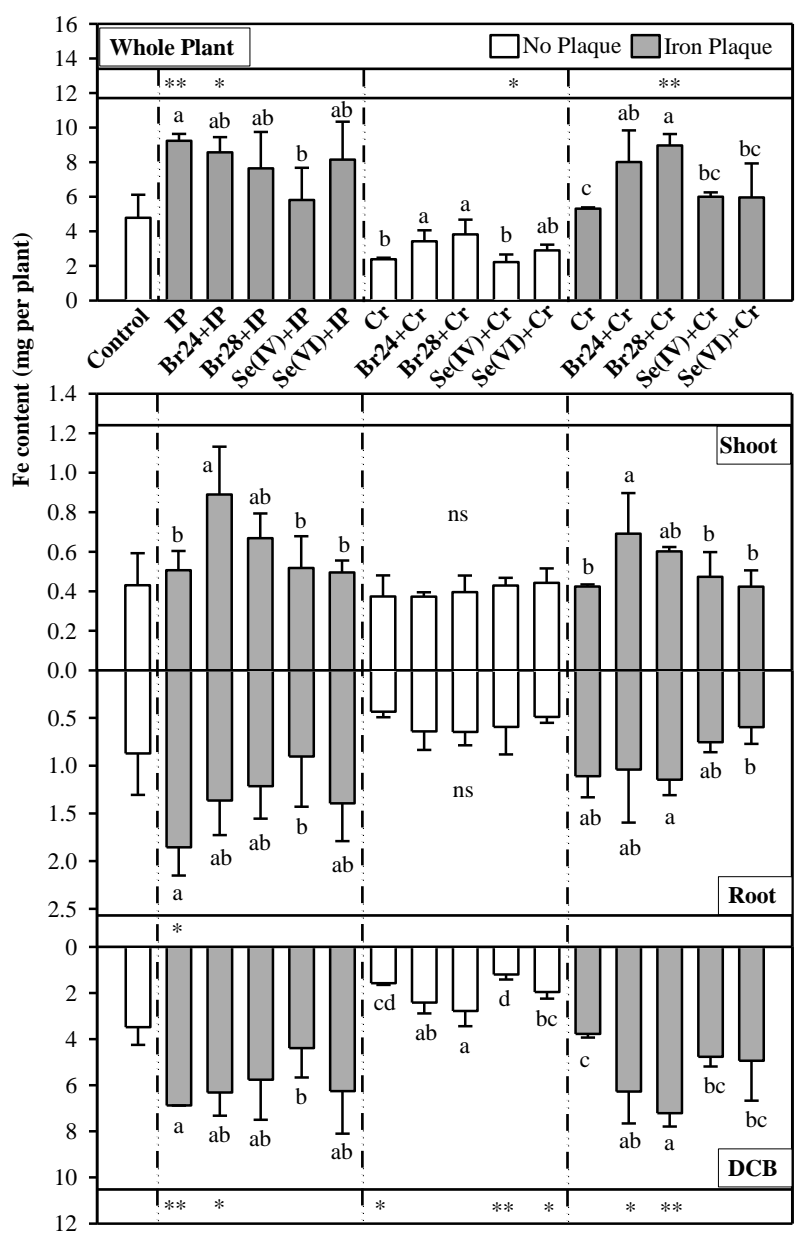

Fig. 3: Distribution of iron $(\mathrm{Fe})$ in shoot, root, dithionitecitrate-bicarbonate (DCB) extract and the whole plant of $I$. pseudacorus (yellow flag) seedlings with brassinosteroid (24-epibrassinolide $(\mathrm{Br} 24): 0.1 \mathrm{mg} \mathrm{L}^{-1}$ and 28homobrassinolide $(\mathrm{Br} 28): 0.1 \mathrm{mg} \mathrm{\textrm {L } ^ { - 1 }}$ ) and selenium (Se(IV): $0.5 \mathrm{mg} \mathrm{L}^{-1}$ and $\left.\mathrm{Se}(\mathrm{VI}): 0.5 \mathrm{mg} \mathrm{L}^{-1}\right)$ ) with or without iron plaque (IP) $\left(\mathrm{Fe}^{2+}: 0\right.$ or $\left.60 \mathrm{mg} \mathrm{L}^{-1}\right)$ under 0 or $0.5 \mathrm{mg} \mathrm{L}^{-1}$ hexavalent chromium $(\mathrm{Cr}(\mathrm{VI}))$ stress. Contents of Fe in shoot, root and DCB extract were presented as mg each plant. Different letters indicate significant differences at $p<0.05$ at IP, no plaque or IP $+\mathrm{Cr}$ group in shoot, root, DCB extract and the whole plant of yellow flag seedlings. The "**" or “**” labeled bars mean significant differences between control and other treatment at $p<0.05$ or $p<0.01$. Data are means $\pm \mathrm{SD}, n=3$.

\section{Discussion}

$\mathrm{Cr}(\mathrm{VI})$ stress could cause Fe deficiency in plants through competing electron carriers of $\mathrm{Fe}$ and $\mathrm{Cu}$ to inhibit electron transport (Dixit et al., 2002). Gopal et al. (2009) reported that $\mathrm{Fe}$ concentrations in spinach were significantly reduced by $\mathrm{Cr}(\mathrm{VI})$, which led to a decrease in chlorophyll and heme biosynthesis. Our results showed that $\mathrm{Cr}(\mathrm{VI})$ stress 


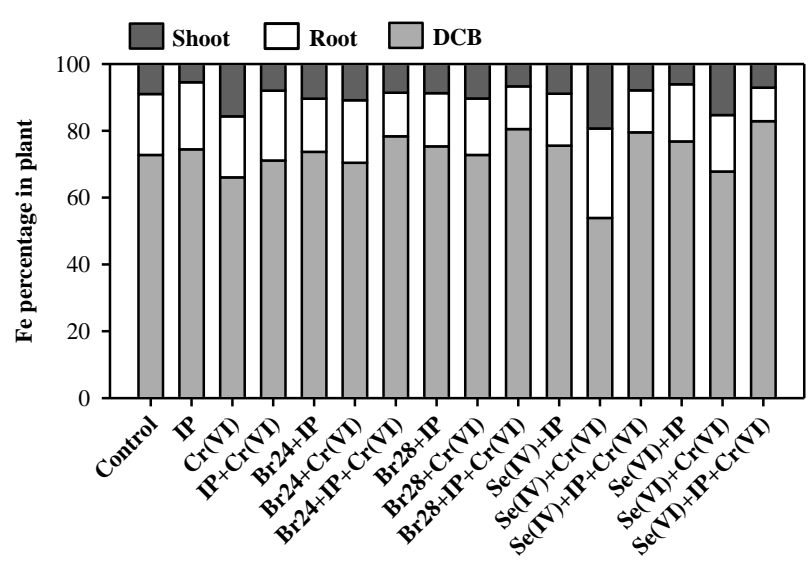

Fig. 4: Percentages of iron $(\mathrm{Fe})$ in shoot, root and dithionite-citrate-bicarbonate (DCB) extract I. pseudacorus (yellow flag) seedlings with brassinosteroid (24epibrassinolide $(\mathrm{Br} 24): 0.1 \quad \mathrm{mg} \quad \mathrm{L}^{-1}$ and 28 homobrassinolide ( $\mathrm{Br} 28): 0.1 \mathrm{mg} \mathrm{\textrm {L } ^ { - 1 }}$ ) and selenium (Se(IV): $0.5 \mathrm{mg} \mathrm{L}^{-1}$ and $\left.\mathrm{Se}(\mathrm{VI}): 0.5 \mathrm{mg} \mathrm{L}^{-1}\right)$ ) with or without iron plaque (IP) $\left(\mathrm{Fe}^{2+}: 0\right.$ or $\left.60 \mathrm{mg} \mathrm{L}^{-1}\right)$ under 0 or $0.5 \mathrm{mg} \mathrm{L}^{-1}$ hexavalent chromium $(\mathrm{Cr}(\mathrm{VI}))$ stress. Data are means $\pm \mathrm{SD}, n=3$

markedly reduced Fe content in yellow flag in the presence of IP (Table 1). We also found that $\mathrm{Br} 24$ and $\mathrm{Br} 28$ counteracted the loss of Fe in DCB extracts and the whole plants exposed to $\mathrm{Cr}(\mathrm{VI})$ with or without IP (Fig. 3). Song et al. (2016) showed that $\mathrm{Br} 24$ could enhance Fe content and positively regulate peanut growth under $\mathrm{Fe}$ deficiency. In addition, our results revealed that $\mathrm{Cr}(\mathrm{VI})$ stress reduced the concentrations of nutrient elements $(\mathrm{Zn}, \mathrm{Mn}$ and $\mathrm{B})$ in yellow flag (Fig. 8). These finding were in line with the reports of previous study showing that $\mathrm{Cr}(\mathrm{VI})$ resulted in reduced $\mathrm{Cu}$ and $\mathrm{Zn}$ in $A$. viridis, rice and barley (Liu et al., 2008a; Sundaramoorthy et al., 2010; Ali et al., 2011), and B in Spartina argentinensis (Redondo-Gomez et al., 2011). However, in the present study, $\mathrm{Br}(\mathrm{Br} 24$ and $\mathrm{Br} 28)$ ameliorated $\mathrm{Zn}$ and $\mathrm{B}$ loss in root of yellow flag with IP (Fig. 8). Talaat and Abdallah (2010) reported that Br24 and $\mathrm{Br} 28$ could enhance the concentrations of $\mathrm{Fe}$ and other nutrient elements in faba bean. The reason for neutralization in loss of $\mathrm{Fe}$ and other microelements may be attributed to the role of $\mathrm{Br}$ in regulating or keeping ion homeostasis in pants with or without heavy metal stress. For example, Br24 could keep cell normal metabolism, restore ATP content and maintain ion balance $(\mathrm{K}, \mathrm{P}, \mathrm{Na}, \mathrm{Mg}, \mathrm{Cl}, \mathrm{Fe}$ and $\mathrm{Mn})$ in cucumber plants (Yuan et al., 2015). Br significantly enhanced content of chlorophyll, protein and monosaccharides and number of cells of Chlorella vulgaris under $\mathrm{Cd}, \mathrm{Pb}$ and $\mathrm{Cu}$ stress (Bajguz, 2011).

In the present study, IP enhanced $\mathrm{Cr}$ accumulation and uptake in DCB extracts and whole plants (Fig. 6). Our results agreed with the findings of $\mathrm{Hu}$ et al. (2014a) who

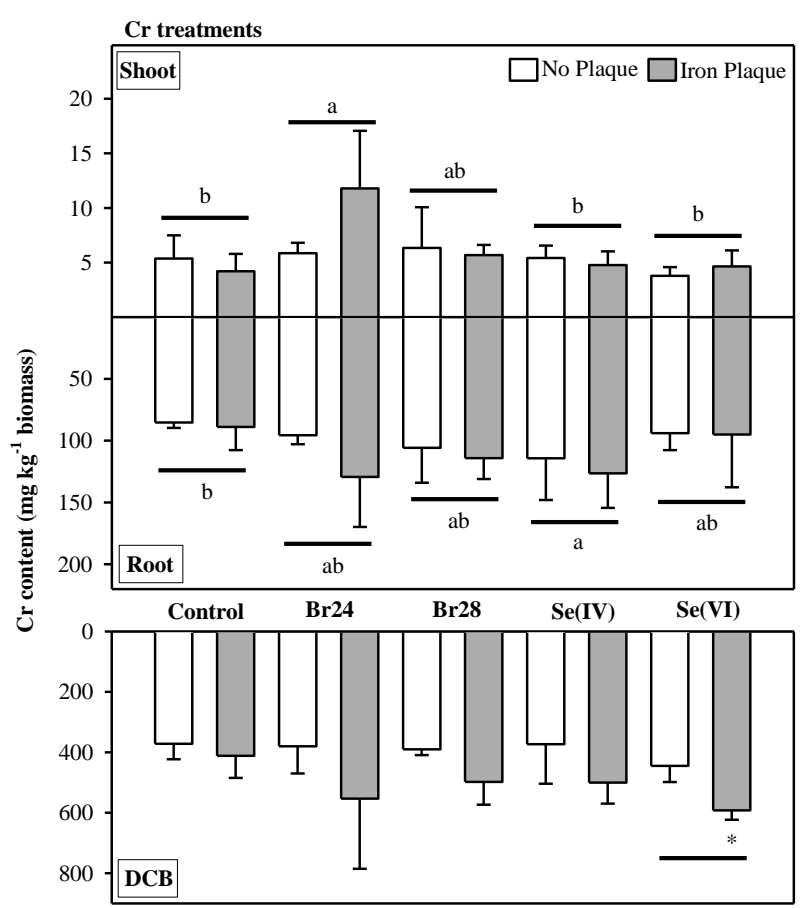

Fig. 5: Distribution of chromium $(\mathrm{Cr})$ in shoot, root and dithionite-citrate-bicarbonate (DCB) extract of $I$. pseudacorus (yellow flag) seedlings exposed to $0.5 \mathrm{mg} \mathrm{L}^{-1}$ hexavalent chromium $(\mathrm{Cr}(\mathrm{VI}))$ with brassinosteroid (24epibrassinolide (Br24): $0.1 \quad \mathrm{mg} \quad \mathrm{L}^{-1}$ and 28homobrassinolide $(\mathrm{Br} 28)$ : $\left.0.1 \mathrm{mg} \mathrm{L}^{-1}\right)$ and selenium (Se(IV): $0.5 \mathrm{mg} \mathrm{L}^{-1}$ and $\left.\mathrm{Se}(\mathrm{VI}): 0.5 \mathrm{mg} \mathrm{L}^{-1}\right)$ ) with or without iron plaque (IP) $\left(\mathrm{Fe}^{2+}: 0\right.$ or $\left.60 \mathrm{mg} \mathrm{L}^{-1}\right)$. Contents of $\mathrm{Cr}$ in shoot, root and DCB extract were presented as $\mathrm{mg}$ $\mathrm{kg}^{-1}$ biomass weight. Different letters indicate significant differences at $p<0.05$ among different treatments in shoot, root and DCB extract of yellow flag seedlings. The “*” labeled bars mean significant differences between no plaque and IP group at $p<0.05$. Data are means $\pm \mathrm{SD}, n=3$

found that IP could immobilize $\mathrm{Cr}$ but did not affect its uptake and translocation in rice plants, and $\mathrm{Xu}$ et al. (2015) who reported that IP improved $\mathrm{Cr}$ adsorption in DCB extracts and increased $\mathrm{Cr}$ uptake by yellow flag. Our results showed that $\mathrm{Br} 24$ and $\mathrm{Br} 28$ could increase $\mathrm{Cr}$ uptake by yellow flag (Fig. 6). Many previous studies reported that $\mathrm{Br} 24$ and $\mathrm{Br} 28$ could reduce the concentrations of metal(loid)s (Ni, $\mathrm{Zn}, \mathrm{Cu}$ and $\mathrm{B}$ ) and alleviate their toxicity in plants (Sharma and Bhardwaj, 2007; Sharma et al., 2008; Kanwar et al., 2013; Ramakrishna and Rao, 2013; Surgun et al., 2016). Their results suggested that $\mathrm{Br}(\mathrm{Br} 24$ and $\mathrm{Br} 28)$ could decrease metal (loid)s uptake by plants via enhancing the activities of glutathione metabolism and biosynthesis and antioxidant enzymes. However, Bukhari et al. (2016) found that $\mathrm{Cr}$ concentrations in the leaves of the Meiyu2-1 and $\mathrm{NC107}$ genotype tomato plants were significantly reduced by $\mathrm{Br} 24$, but were increased in 2010-38 genotype. 


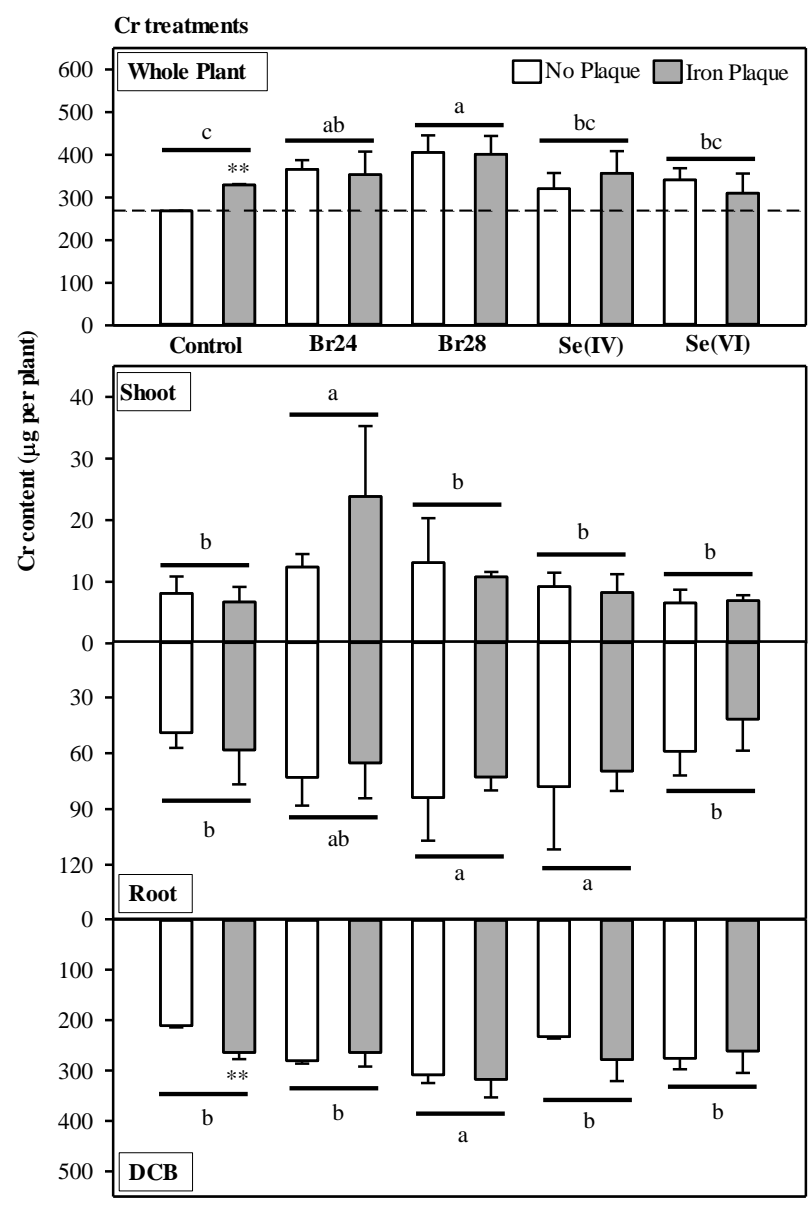

Fig. 6: Distribution of chromium $(\mathrm{Cr})$ in shoot, root, dithionite-citrate-bicarbonate (DCB) extract and the whole plant of I. pseudacorus (yellow flag) seedlings exposed to $0.5 \mathrm{mg} \quad \mathrm{L}^{-1}$ hexavalent chromium $(\mathrm{Cr}(\mathrm{VI}))$ with brassinosteroid (24-epibrassinolide (Br24): $0.1 \mathrm{mg} \mathrm{L}^{-1}$ and 28-homobrassinolide $\left.(\mathrm{Br} 28): 0.1 \mathrm{mg} \mathrm{L}^{-1}\right)$ and selenium (Se(IV): $0.5 \mathrm{mg} \mathrm{L}^{-1}$ and $\left.\mathrm{Se}(\mathrm{VI}): 0.5 \mathrm{mg} \mathrm{L}^{-1}\right)$ ) with or without iron plaque (IP) $\left(\mathrm{Fe}^{2+}: 0\right.$ or $\left.60 \mathrm{mg} \mathrm{L}^{-1}\right)$. Contents of $\mathrm{Cr}$ in shoot, root, DCB extract and the whole plant were presented as $\mu \mathrm{g}$ each plant. Different letters indicate significant differences at $p<0.05$ among different treatments in shoot, root, DCB extract and the whole plant of yellow flag seedlings. The "**" labeled bars mean significant differences between no plaque and IP group at $p$ $<0.01$. Data are means $\pm \mathrm{SD}, n=3$.

Sharma et al. (2011) also reported that $\mathrm{Br} 28$ markedly increased $\mathrm{Cr}$ uptake by Raphanus sativus $\mathrm{L}$. Thus it can be seen that different element type and plant genotype may result in the observed difference.

Meanwhile, we found that $\mathrm{Se}(\mathrm{IV})$ and $\mathrm{Se}(\mathrm{VI})$ could improve $\mathrm{Cr}$ accumulation and uptake by yellow flag (Fig. 5 and 6). Our results were in line with the findings of Qing et al. (2015) who reported that Se(IV) did not affect $\mathrm{Cr}$ translocation and uptake by cabbage leaves, but increased $\mathrm{Cr}$

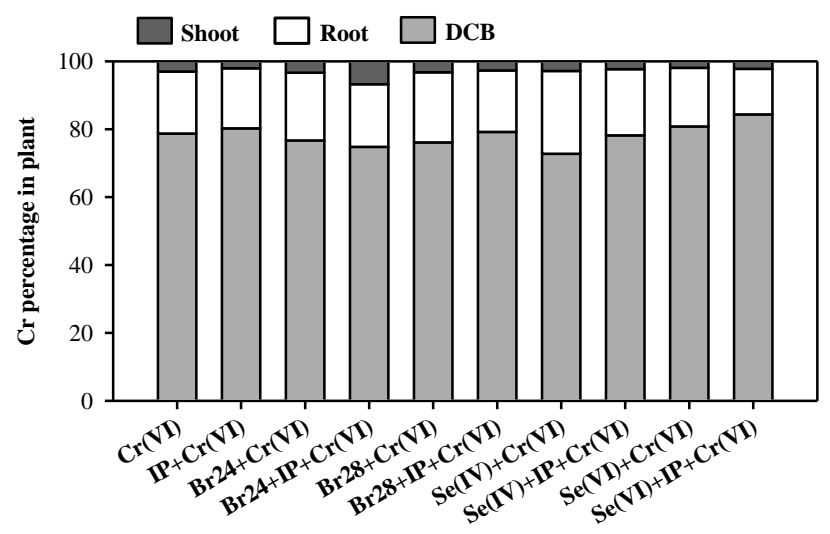

Fig. 7: Percentages of chromium $(\mathrm{Cr})$ in shoot, root and dithionite-citrate-bicarbonate (DCB) extract I. pseudacorus (yellow flag) seedlings exposed to $0.5 \mathrm{mg} \mathrm{L}^{-1}$ hexavalent chromium $(\mathrm{Cr}(\mathrm{VI}))$ with brassinosteroid (24epibrassinolide (Br24): $0.1 \quad \mathrm{mg} \quad \mathrm{L}^{-1}$ and 28homobrassinolide $\left.(\mathrm{Br} 28): 0.1 \mathrm{mg} \mathrm{L}^{-1}\right)$ and selenium (Se(IV): $0.5 \mathrm{mg} \mathrm{L}^{-1}$ and $\left.\mathrm{Se}(\mathrm{VI}): 0.5 \mathrm{mg} \mathrm{L}^{-1}\right)$ ) with or without iron plaque (IP). Data are means $\pm \mathrm{SD}, n=3$.

content by $20 \%$ at least. Se possibly combined with $\mathrm{Cd}, \mathrm{Hg}$ and $\mathrm{Ag}$ and formed Se-metal complexes, which alleviated their toxicity to plants (Shanker et al., 1996; Sasakura and T. Suzuki, 1998; Belzile et al., 2006; Fargasova et al., 2006; Feng et al., 2013). However, Bluemlein et al. (2009) showed that no complexes or peptides of Se(IV) and $\mathrm{As}(\mathrm{V})$ were found, although Se significantly enhanced As uptake by Thunbergia alata. The difference may occur partly as a result of poor sulfur assimilation. The transport of $\mathrm{Se}(\mathrm{VI})$ into plant cells could be mediated by sulfate carriers (MaruyamaNakashita et al., 2007; Schiavon et al., 2007). Se can compete with sulfur for the binding site of sulfate transporters and repress its transport and uptake by plants (Ellis and Salt, 2003; Schiavon et al., 2007). In the present study, yellow flag was grown in nutrient solution with 0.5 $\mathrm{mg} \mathrm{L}{ }^{-1}$ Se for 1 week before $\mathrm{Cr}$ treatment. Hence, Se supply possibly substituted sulfur for proteins to some extent, resulting in the reduced synthesis of important amino acids such as cysteine, methionine, and glutathione (Michela and Mario, 2008), which could significantly decrease Cr uptake by plants (Lay and Levina, 1996; Yu et al., 2007; Zeng et al., 2012). Consequently, more $\mathrm{Cr}$ could be translocated into plants due to the reduced synthesis of these amino acids, which could explain the increased $\mathrm{Cr}$ accumulation by yellow flag with Se supply in our study.

\section{Conclusion}

$\mathrm{Cr}$ stress decreased $\mathrm{Fe}$ accumulation and uptake by yellow flag, but $\mathrm{Br}$ significantly neutralized this effect regardless of formation or not of IP. $\mathrm{Cr}$ exposure reduced the concentrations of microelements ( $\mathrm{Zn}, \mathrm{Mn}$ and $\mathrm{B}$ ) in yellow flag; and IP, Br, Se and the combined effects of IP 


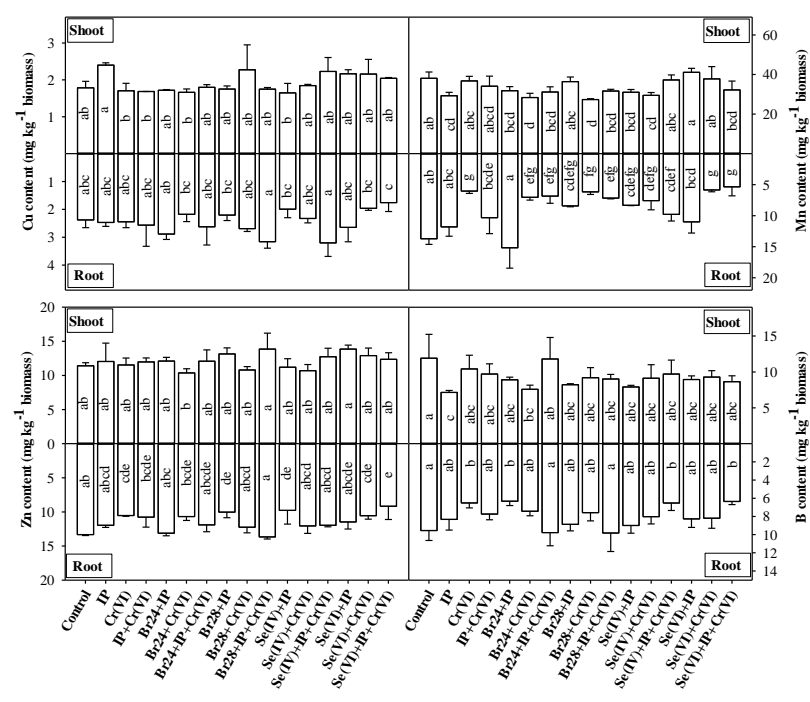

Fig. 8: Distribution of copper $(\mathrm{Cu})$, manganese $(\mathrm{Mn})$, zinc (Zn) and boron (B) in shoot and root tissue of I. pseudacorus (yellow flag) seedlings with brassinosteroid (24epibrassinolide (Br24): $0.1 \mathrm{mg} \mathrm{L}^{-1}$ and 28-homobrassinolide (Br28): $0.1 \mathrm{mg} \mathrm{L}^{-1}$ ) and selenium (Se(IV): $0.5 \mathrm{mg} \mathrm{L}^{-1}$ and $\left.\left.\mathrm{Se}(\mathrm{VI}): 0.5 \mathrm{mg} \mathrm{L}^{-1}\right)\right)$ with or without iron plaque (IP) $\left(\mathrm{Fe}^{2+}: 0\right.$ or $60 \mathrm{mg} \mathrm{L}^{-1}$ ) under 0 or $0.5 \mathrm{mg} \mathrm{L}^{-1}$ hexavalent chromium $(\mathrm{Cr}(\mathrm{VI}))$ stress. Contents of $\mathrm{Cu}, \mathrm{Mn}, \mathrm{Zn}$ and $\mathrm{B}$ in shoot, root and DCB extract were presented as $\mathrm{mg} \mathrm{kg}^{-1}$ biomass weight. Different letters indicate significant differences at $p<0.05$ in shoot and root tissue of yellow flag seedlings. Data are means $\pm \mathrm{SD}, n=3$

and $\mathrm{Br}$ or $\mathrm{Se}$ counteracted their loss to some extent. IP markedly increased $\mathrm{Cr}$ enrichment by $36 \%$; $\mathrm{Br} 24$ and $\mathrm{Br} 28$ significantly enhanced $\mathrm{Cr}$ accumulation and uptake and increased $\mathrm{Cr}$ enrichment by $36 \%$ and $51 \%$ in the absence of IP, and $7 \%$ and $21 \%$ in the presence of IP. Se also improved $\mathrm{Cr}$ accumulation by yellow flag although the difference was not statistically significant. To what extent the application of exogenous $\mathrm{Br}$ or $\mathrm{Se}$ can more effectively increase $\mathrm{Cr}$ accumulation in yellow flag requires further studies.

\section{Acknowledgements}

This work was supported by the National Natural Science Foundation of China (31500319), the National and Fujian Provincial College Student's Innovative Entrepreneurial Training Program of China (201610389015 and 201610389084).

\section{References}

Ahammed, G.J., S.P. Choudhary, S.C. Chen, X.J. Xia, K. Shi, Y.H. Zhou and J.Q. Yu, 2013. Role of brassinosteroids in alleviation of phenanthrenecadmium co-contamination-induced photosynthetic inhibition and oxidative stress in tomato. J. Exp. Bot., 64: 199-213

Ali, S., F.R. Zeng, B.Y. Qiu, S.G. Cai, L. Qiu, F.B. Wu and G.P. Zhang, 2011. Interactive effects of aluminum and chromium stresses on the uptake of nutrients and the metals in barley. Soil Sci. Plant Nutr, 57: $68-79$
Armstrong, W., 1964. Oxygen diffusion from the roots of some British bog plants. Nature, 204: 801-802

Bajguz, A., 2011. Suppression of chlorella vulgaris growth by cadmium, lead, and copper stress and its restoration by endogenous brassinolide. Arch. Environ. Contam. Toxicol., 60: 406-416

Ballesteros, S., J.M. Rincón, B. Rincón-Mora and M.M. Jordán, 2017. Vitrification of urban soil contamination by hexavalent chromium. $J$. Geochem. Explor., 174: 132-139

Batty, L.C., A.J.M. Baker, B.D. Wheeler and C.D. Curtis, 2000. The effect of $\mathrm{pH}$ and plaque on the uptake of $\mathrm{Cu}$ and $\mathrm{Mn}$ in Phragmites australis (Cav.) Trin ex. steudel. Ann. Bot., 86: 647-653

Belzile, N., G.J. Wu, Y.W. Chen and V.D. Appanna, 2006. Detoxification of selenite and mercury by reduction and mutual protection in the assimilation of both elements by Pseudomonas fluorescens. Sci. Total Environ., 367: 704-714

Bluemlein, K., E. Klimm, A. Raab and J. Feldmann, 2009. Selenite enhances arsenate toxicity in Thunbergia alata. Environ. Chem., 6: 486-494

Bukhari, S.A.H., R.F. Wang, W. Wang, I.M. Ahmed, W.T. Zheng and F.B. Cao, 2016. Genotype-dependent effect of exogenous 24epibrassinolide on chromium-induced changes in ultrastructure and physicochemical traits in tobacco seedlings. Environ. Sci. Pollut. Res., 23: 18229-18238

Cartes, P., A.A. Jara, L. Pinilla, A. Rosas and M.L. Mora, 2010. Selenium improves the antioxidant ability against aluminium-induced oxidative stress in ryegrass roots. Ann. Appl. Biol., 156: 297-307

Clouse, S.D. and J.M. Sasse, 1998. BRASSINOSTEROIDS: Essential regulators of plant growth and development. Annu. Rev. Plant Physiol. Plant Mol. Biol., 49: 427-451

Dixit, V., V. Pandey and R. Shyam, 2002. Chromium ions inactivate electron transport and enhance superoxide generation in vivo in pea (Pisum sativum L. cv. Azad) root mitochondria. Plant Cell Environ., 25: 687-693

Ellis, D.R. and D.E. Salt, 2003. Plants, selenium and human health. Curr. Opin. Plant Biol., 6: 273-279

Fargasova, A., J. Pastierova and K. Svetkova, 2006. Effect of Se-metal pair combinations $(\mathrm{Cd}, \mathrm{Zn}, \mathrm{Cu}, \mathrm{Pb})$ on photosynthetic pigments production and metal accumulation in Sinapis alba L. seedlings. Plant Soil Environ., 52: 8-15

Fariduddin, Q., M. Yusuf, I. Ahmad and A. Ahmad, 2014. Brassinosteroids and their role in response of plants to abiotic stresses. Biol. Plant., 58: $9-17$

Feng, R.W., C.Y. Wei and S.X. Tu, 2013. The roles of selenium in protecting plants against abiotic stresses. Environ. Exp. Bot., 87: 58-68

Gao, Y. and J. Xia, 2011. Chromium Contamination Accident in China: Viewing Environment Policy of China. Environ. Sci. Technol., 45: 8605-8606

Gopal, R., A.H. Rizvi and N. Nautiyal, 2009. Chromium alters iron nutrition and water relations of spinach. J. Plant Nutr., 32: 1551-1559

Hansel, C.M., S. Fendorf, S. Sutton and M. Newville, 2001. Characterization of $\mathrm{Fe}$ plaque and associated metals on the roots of mine-waste impacted aquatic plants. Environ. Sci. Technol., 35: 3863-3868

Hashim, M.A., S. Mukhopadhyay, J.N. Sahu and B. Sengupta, 2011. Remediation technologies for heavy metal contaminated groundwater. J. Environ. Manage., 92: 2355-2388

Hu, Y., Y.Z. Huang and Y.X. Liu, 2014a. Influence of iron plaque on chromium accumulation and translocation in three rice (Oryza sativa L.) cultivars grown in solution culture. Chem. Ecol., 30: $29-38$

Hu, Y., G.J. Norton, G.L. Duan, Y.C. Huang and Y.X. Liu, 2014b. Effect of selenium fertilization on the accumulation of cadmium and lead in rice plants. Plant Soil, 384: 131-140

Kanwar, M.K., R. Bhardwaj, S.P. Chowdhary, P. Arora, P. Sharma and S. Kumar, 2013. Isolation and characterization of 24-Epibrassinolide from Brassica juncea $\mathrm{L}$. and its effects on growth, $\mathrm{Ni}$ ion uptake, antioxidant defense of Brassica plants and in vitro cytotoxicity. Acta Physiol. Plant., 35: 1351-1362

Lai, W.L., Y. Zhang and Z.H. Chen, 2012. Radial oxygen loss, photosynthesis, and nutrient removal of 35 wetland plants. Ecol. Eng., 39: 24-30 
Lay, P.A. and A. Levina, 1996. Kinetics and mechanism of chromium(VI) reduction to chromium (III) by L-cysteine in neutral aqueous solutions. Inorg. Chem., 35: 7709-7717

Liu, D.H., J.H. Zou, M. Wang and W.S. Jiang, 2008a. Hexavalent chromium uptake and its effects on mineral uptake, antioxidant defence system and photosynthesis in Amaranthus viridis L. Bioresour. Technol., 99: 2628-2636

Liu, H.J., J.L. Zhang, P. Christie and F.S. Zhang, 2008b. Influence of iron plaque on uptake and accumulation of Cd by rice (Oryza sativa L.) seedlings grown in soil. Sci. Total Environ., 394: 361-368

Liu, H.J., J.L. Zhang and F.S. Zhang, 2007. Role of iron plaque in Cd uptake by and translocation within rice (Oryza sativa L.) seedlings grown in solution culture. Environ. Exp. Bot., 59: 314-320

Liu, W.J., Y.G. Zhu, F.A. Smith and S.E. Smith, 2004. Do iron plaque and genotypes affect arsenate uptake and translocation by rice seedlings (Oryza sativa L.) grown in solution culture? J. Exp. Bot., 55: 17071713

Mang, X.B., P. Liu, Y.S. Yang and W.R. Chen, 2007. Phytoremediation of urban wastewater by model wetlands with ornamental hydrophytes. J. Environ. Sci., 19: 902-909

Maruyama-Nakashita, A., E. Inoue, K. Saito and H. Takahashi, 2007. Sulfur-responsive promoter of sulfate transporter gene is potentially useful to detect and quantify selenate and chromate. Plant Biotechnol., 24: 261-263

Mashkoor, J., A. Khan, M.Z. Khan and I. Hussain, 2016. Chromium toxicity and oxidative stress in broiler chicks and its amelioration with vitamin E and bentonite. Int. J. Agric. Biol., 18: 1103-1108

Michela, S. and M. Mario, 2008. Role of Sulfate and S-Rich Compounds in Heavy Metal Tolerance and Accumulation. In: Sulfur Assimilation and Abiotic Stress in Plants, pp: 253-269. Springer-Verlag, Heidelberg, Berlin, Germany

Qing, X.J., X.H. Zhao, C.X. Hu, P. Wang, Y. Zhang, X. Zhang, P.C. Wang, H.Z. Shi, F. Jia and C.J. Qu, 2015. Selenium alleviates chromium toxicity by preventing oxidative stress in cabbage (Brassica campestris L. ssp Pekinensis) leaves. Ecotoxicol. Environ. Saf., 114: 179-189

Rai, D., L.E. Eary and J.M. Zachara, 1989. Environmental chemistry of chromium. Sci. Total Environ., 86: 15-23

Ramakrishna, B. and S.S.R. Rao, 2013. Preliminary studies on the involvement of glutathione metabolism and redox status against zinc toxicity in radish seedlings by 28 -Homobrassinolide. Environ. Exp. Bot., 96: 52-58

Redondo-Gomez, S., E. Mateos-Naranjo, I. Vecino-Bueno and S.R. Feldman, 2011. Accumulation and tolerance characteristics of chromium in a cordgrass Cr-hyperaccumulator, Spartina argentinensis. J. Hazard. Mater., 185: 862-869

Richard, F.C. and A.C.M. Bourg, 1991. Aqueous geochemistry of chromium: A review. Water Res., 25: 807-816

Sasakura, C. and K. T. Suzuki, 1998. Biological interaction between transition metals (Ag, $\mathrm{Cd}$ and $\mathrm{Hg}$ ), selenide/sulfide and selenoprotein P. J. Inorg. Biochem., 71: 159-162

Schiavon, M., M. Wirtz, P. Borsa, S. Quaggicitti, R. Hell and M. Malagoli, 2007. Chromate differentially affects the expression of a high-affinity sulfate transporter and isoforms of components of the sulfate assimilatory pathway in Zea mays (L.). Plant Biol., 9: 662-671

Shanker, K., S. Mishra, S. Srivastava, R. Srivastava, S. Dass, S. Prakash and M.M. Srivastava, 1996. Study of mercury-selenium ( $\mathrm{Hg} \mathrm{Se})$ interactions and their impact on $\mathrm{Hg}$ uptake by the radish (Raphanus sativus) plant. Food Chem. Toxicol., 34: 883-886

Sharma, I., P.K. Pati and R. Bhardwaj, 2011. Effect of 28-homobrassinolide on antioxidant defence system in Raphanus sativus L. under chromium toxicity. Ecotoxicology, 20: 862-874

Sharma, P. and R. Bhardwaj, 2007. Effects of 24-epibrassinolide on growth and metal uptake in Brassica juncea L. under copper metal stress. Acta Physiol. Plant., 29: 259-263

Sharma, P., R. Bhardwaj, N. Arora, H.K. Arora and A. Kumar, 2008. Effects of 28-homobrassinolide on nickel uptake, protein content and antioxidative defence system in Brassica juncea. Biol. Plant., 52: $767-770$
Singh, O.V., S. Labana, G. Pandey, R. Budhiraja and R.K. Jain, 2003. Phytoremediation: an overview of metallic ion decontamination from soil. Appl. Microbiol. Biotechnol., 61: 405-412

Smith, C.J., S.D. Livingston and D.J. Doolittle, 1997. An international literature survey of "IARC group I carcinogens" reported in mainstream cigarette smoke. Food Chem. Toxicol., 35: 1107-1130

Song, Y.L., Y.J. Dong, X.Y. Tian, J. Kong, X.Y. Bai, L.L. Xu and Z.L. He, 2016. Role of foliar application of 24-epibrassinolide in response of peanut seedlings to iron deficiency. Biol. Plant., 60: 329-342

Srivastava, M., L.Q. Ma, B. Rathinasabapathi and P. Srivastava, 2009. Effects of selenium on arsenic uptake in arsenic hyperaccumulator Pteris vittata L. Bioresour. Technol., 100: 1115-1121

Sundaramoorthy, P., A. Chidambaram, K.S. Ganesh, P. Unnikannan and L. Baskaran, 2010. Chromium stress in paddy: (i) Nutrient status of paddy under chromium stress; (ii) Phytoremediation of chromium by aquatic and terrestrial weeds. C. R. Biol., 333: 597-607

Surgun, Y., B. Col and B. Burun, 2016. 24-Epibrassinolide ameliorates the effects of boron toxicity on Arabidopsis thaliana (L.) Heynh by activating an antioxidant system and decreasing boron accumulation. Acta Physiol. Plant., 38: 71

Talaat, N.B. and A.M. Abdallah, 2010. Effect of 28-homobrassinolide and 24-epibrassinolide on the growth, productivity and nutritional value of two faba bean (Vicia faba L.) cultivars. Arch. Agron. Soil Sci., 56: 649-669

Taylor, G.J. and A.A. Crowder, 1983. Use of the DCB technique for extraction of hydrous iron-oxides from roots of wetland plants. Amer. J. Bot., 70: 1254-1257

Taylor, G.J., A.A. Crowder and R. Rodden, 1984. Formation and morphology of an iron plaque on the roots of Typha latifolia $\mathrm{L}$. grown in solution culture. Amer. J. Bot., 71: 666-675

Weiss, J.V., D. Emerson and J.P. Megonigal, 2004. Geochemical control of microbial Fe (III) reduction potential in wetlands: comparison of the rhizospheretonon-rhizosphere soil.FEMSMicrobiol.Ecol., 48: 89-100

Wu, C., Z.H. Ye, H. Li, S.C. Wu, D. Deng, Y.G. Zhu and M.H. Wong, 2012. Do radial oxygen loss and external aeration affect iron plaque formation and arsenic accumulation and speciation in rice? J. Exp. Bot., 63: 2961-2970

Xia, W., J. Hu, B. Zhang, Y.Y. Li, J.P. Wise, B.A. Bassig, A.F. Zhou, D.A. Savitz, C. Xiong, J.Z. Zhao, X.F. Du, Y.Q. Zhou, X.Y. Pan, J. Yang, C.S. Wu, M.M. Jiang, Y. Peng, Z.M. Qian, T.Z. Zheng and S.Q. Xu, 2016. A case-control study of maternal exposure to chromium and infant low birth weight in China. Chemosphere, 144: 1484-1489

$\mathrm{Xu}, \mathrm{B}$. and S. Yu, 2013. Root iron plaque formation and characteristics under $\mathrm{N}_{2}$ flushing and its effects on translocation of $\mathrm{Zn}$ and $\mathrm{Cd}$ in paddy rice seedlings (Oryza sativa). Ann. Bot., 111: 1189-1195

Xu, B., S. Yu, J. Ding, S.C. Wu and J. Ma, 2015. Metal-dependent root iron plaque effects on distribution and translocation of chromium and nickel in yellow flag (Iris pseudacorus L.). Int. J. Phytoremed., 17: 175-181

Ye, Z.H., A.J.M. Baker, M.H. Wong and A.J. Willis, 1998. Zinc, lead and cadmium accumulation and tolerance in Typha latifolia as affected by iron plaque on the root surface. Aquat. Bot., 61: 55-67

Ye,Z.H., K.C.Cheung and M.H. Wong, 2003. Cadmium and nickel adsorption and uptake in cattail as affected by iron and manganese plaque on the root surface. Commun. Soil Sci. Plant Anal., 34: 2763-2778

Yu, J.Q., L.F. Huang, W.H. Hu, Y.H. Zhou, W.H. Mao, S.F. Ye and S. Nogues, 2004. A role for brassinosteroids in the regulation of photosynthesis in Cucumis sativus. J. Exp. Bot., 55: 1135-1143

Yu, X.Z., J.D. Gu and S.Z. Huang, 2007. Hexavalent chromium induced stress and metabolic responses in hybrid willows. Ecotoxicology, 16 : 299-309

Yuan, L.Y., S.D. Zhu, S. Shu, J. Sun and S.R. Guo, 2015. Regulation of 2,4epibrassinolide on mineral nutrient uptake and ion distribution in $\mathrm{Ca}\left(\mathrm{NO}_{3}\right)_{2}$ stressed cucumber plants. J. Plant Physiol., 188: 29-36

Zeng, F.R., B.Y. Qiu, X.J. Wu, S.Z. Niu, F.B. Wu and G.P. Zhang, 2012. Glutathione-mediated alleviation of chromium toxicity in rice plants. Biol. Trace Elem. Res., 148: 255-263

(Received 30 December 2016; Accepted 01 March 2017) 